\title{
Védőoltások a Covid-19-pandémia ellen
}

\author{
FALUS ANDRÁS, SZEKANECZ ZOLTÁN
}

A gyorsan terjedő SARS-CoV-2 légzôszervi vírus súlyos következményekkel járó járványt okozott az egész világon. Az egészségügyi hatások mellett a globális gazdasági károk ma még felmérhetetlenek. A világjárvány ugyanakkor soha nem látott tudományos kutatások sorát indította el, többek között a védőoltások kidolgozása terén.

A cikk a vakcinákról, az immunmemóriáról és az egyes felvetődő klinikai hatásokról szóló aktuális információkat foglalja össze.

Covid-19, SARS-CoV-2, védóoltás

\section{VACCINES AGAINST COVID-19 PANDEMIC}

The rapidly spreading SARS-CoV2 respiratory virus has evoked an epidemic with serious aftermath around the world. In addition to the health effects, the global economic damage is actually unpredictable. At the same time, the pandemic has launched a series of unprecedented collaborative scientific research, including the development of vaccines. This study summarizes up-to-date information on vaccines, immune memory, and some emerging clinical effects.

Covid-19, SARS-CoV-2, vaccine

\footnotetext{
prof. dr. FALUS András (levelező szerző/correspondent): Semmelweis Egyetem, Genetikai, Sejt- és Immunbiológiai Intézet/Semmelweis University, Department of Genetics, Cell- and Immunobiology, H-1089 Budapest, Nagyvárad tér 4. E-mail: afalus@gmail.com

dr. SZEKANECZ Zoltán: Debreceni Egyetem, Belgyógyászati Intézet, Reumatológiai Tanszék/University of Debrecen, Department of Internal Medicine, Rheumatology, Debrecen

Érkezett: 2021. január 21. Elfogadva: 2021. január 31.

https://doi.org/10.33616/lam.31.002
}

A SARS-CoV-2 sosem látott nagy virulenciájával 2020 februárjától világjárványt idézett elő. A pandémia, fôleg az idősebb krónikus betegek jelentôs arányú mortalitásával, érthető ijedtséget okozott és okoz most is, 2021 elején (1). Közel 100 millió fertőzöttről és 2 milliót meghaladó halálos áldozatról tudunk a nemzetközileg naponta frissített internetes webhelyeket felkeresve (például https://www.worldometers.info/coronavirus/). Egyértelmú nemzetközi egyetértés tapasztalható abban, hogy csak a vírusellenes védőoltások fogják azt a populációs védettséget biztosítani, amely elejét veszi a további tömeges fertôzésnek és megbetegedésnek. E sorok írása idején, 2021 januárjában, a hírügynökségek arról számolnak be, hogy több mint 90 védőoltás van már a klinikai kipróbálás különbözô stádiumaiban, közülük hármat már az európai és amerikai gyógyszer-engedélyezési hatóság is széles körú felhasználásra javasolt (https://www.nytimes. com/interactive/2020/science/coronavirusvaccine-tracker.html).

\section{Az immunválasz sémája}

Amikor antigéningerek érik a szervezetet, az adott antigénekre a természetes immunitás nyomán az antigénbemutató sejtek hatékony közremúködésével specifikus lymphocytaklónok aktiválódnak, elszaporodnak, és létrejön az immunválasz. A szerzett immunitás során nemcsak gyorsan ható és viszonylag rövid életú („effektor”) sejtek hada keletkezik, hanem kisebb számban ugyan, de az antigénre specifikus, hosszú életú immunmemória-sejtek is. Ez egy jellegzetes aszimmetrikus változás, az immunmemória-sejtek nemcsak életidejükben, de méretükben is különböznek, kisebbek. 
1. táblázat. Egyes ma ismert SARS-CoV-2 vakcinák fejlesztése és forrása

\begin{tabular}{llll} 
Stratégia & Klinikai fázis & Hány oltást javasol & Cég \\
\hline$m R N S$ & elfogadva & 2 & Pfizer-BioNTech (USA-Németország), BNT-162b2 \\
\hline$m R N S$ & elfogadva & 2 & Moderna (USA) mRNA-1273 \\
\hline vírusvektor & elfogadva & 2 & AstraZeneca (Svédország-Anglia), AZA-1222 ChAd5-CoV \\
\hline vírusvektor & fázis $2 / 3$ & 2 & Gamaleya Sputnik V (Oroszország), Gam-Covid-Vac, Ad26-Ad5 \\
\hline vírusvektor & fázis $2 / 3$ & 1 vagy 2 & Janssen J\&J (USA), Ad26.COV2.S \\
\hline vírusvektor & fázis $2 / 3$ & 2 & CanSino (Kína), Ad5-nCoV (CONVIDECIA) \\
\hline inaktivált vírus & fázis $2 / 3$ & & Sinopharm (Kína) \\
\hline fehérjealegység & fázis $2 / 3$ & 2 & Novavax (USA), NVX-CoV2373 \\
\hline fehérjealegység & fázis $2 / 3$ & & Vaxxinity (USA), UB-612 \\
\hline rekombináns fehérje & fázis 2 & Medigen (Tajvan) \\
\hline inaktivált vírus & & $?$ & SinoVac (Kína) \\
\hline inaktivált vírus & fázis 3 & 3 & Bharat Biotech (India) \\
\hline mRNS & fázis $2 / 3$ & 2 & CureVac (Németország), CVnCoV \\
\hline DNS-vektor & fázis $2 / 3$ & 2 & Inovio (USA) \\
\hline DNS-vektor & fázis $2 / 3$ & 2 & Osaka/Takara (Japán), AG0302-COVID19 \\
\hline DNS-vektor & fázis 3 & 4 & Zydus Cadila (India), ZyCoV-D \\
\hline
\end{tabular}

Az immunrendszer emlékszik a már "látott” antigénre, annak másodszori, harmadik, többedik érkezése gyorsabb, és hatékonyabb immunválaszt eredményez.

\section{Immunmemória}

Az immunmemória ma még sok szempontból nem minden molekuláris részletében feltárt epigenetikai folyamat, de nyilvánvaló, hogy memóriája révén az immunrendszer múködése jelentôsen gazdaságosabbá válik.

Az immunmemória kialakulása antigénspecifikus, jellegzetes membránmarkereket kifejező T- és B-memóriasejtek megjelenésével jár, amelyek nyugalmi állapotban sejtciklusuk Go stádiumában vannak. Az antigén újbóli megjelenése után gyorsan aktiválódva egy részük effektor sejtté, kisebb frakciójuk újra memóriasejtté differenciálódik. A T- és B-sejtes immunmemória között jelentôs a mennyiségi és minőségi különbség, de ami közös bennük az, hogy minden immunológiai aktiváció során a megfelelő gyors, végrehajtó lymphocytasejtek (például ellenanyag-termelő plazmasejt, citotoxikus Tsejt, citokineket termeló segító T-sejt) mellett mindig hosszú életú lymphocyták is kialakulnak, amelyek elvonulva akár egy „félreeső” nyirokcsomóba, ott akár évekig készek az újabb antigénreceptoruknak megfelelő antigénlátogató általi reaktivációra. Jelentős szerepet kapnak a folyamatban a follicularis dendritikus sejtek is, amelyek viszonylag igen hosszú ideig „ébren” (vagy inkább éberen) tartják a memória-B-sejteket. Elképzelhetô, hogy az idiotípus antigéneknek is van szerepük az „ébrenléti állapot” fenntartásában egy hálózatos endogén aktiváció („internal image”) révén.

\section{A védőoltások célja: immunmemória előállítása}

Az aktívan elóidézett, irányított immunizáció, vagyis a vakcináció mesterségesen idéz elő hoszszan tartó, eredményes immunválaszt biztosító immunmemóriát (2). A vakcinákat olyan körülmények között adják, hogy az antigéninger elhúzódó és hosszan tartó legyen. Ez az eredményes és jól múköőó immunemlékezés kialakításának, a védôoltásoknak, a vakcinációnak a tényleges célja. Így egy új, vagy ismétlődő fertőzés egy éberen alvó, könnyen aktiválható immunrendszert talál, amely aktiválódása nyomán gyorsan és eredményesen gyózi le a betolakodót.

A védőoltások hatalmas szolgálatot tettek és tesznek az emberiségnek. Vakcinák hatására túnt el a Földről a fekete himlő, a vakcinák (Salk, Sabin) védenek meg a járványos gyermekbénulás (poliomyelitis) életen át tartó súlyos betegségétől, és többek között a kanyarótól, a mumpsztól, a rózsahimlőtől és az évenként más-más felszíni antigénekkel megjelenő influenzától is. Egyre több rákellenes védőoltás is létezik, ilyen a méhnyakrák, illetve terjedése miatt a here- és péniszrák, sôt a fej-nyak rákok okaként ismert emberi papillomavírus (HPV) elleni oltás. 
E sorok írói nemcsak tévedésnek, hanem súlyos felelőtlenségnek tartják az oltásellenesség minden formáját, mert ez a különböző okokból megjelenó magatartás sokszor demagóg, és tényszerúen valótlan propagandájuk révén megbocsáthatatlan vétek az emberiség egészsége ellen.

\section{A SARS-CoV-2 elleni vakcina elóállítása}

Ma már, elsôsorban a korszerú biotechnológia, informatika és mesterséges intelligenciák segítségével, legalább négyféle vakcinafejlesztési stratégiával próbálkoznak, ezen belül több megoldás is létezik (https://www.ecdc.europa.eu/en/publications-data/overview-current-eu-eea-uk-planscovid-19-vaccines). A leginkább hagyományos módszer legyengített, élố vírusokat vagy elölt, tehát fertőzésképtelen víruspartikulákat használ oltóanyagként. Egy másik út a vírus felszínéről izolált fehérjéket (így a tüskefehérjéket) használ az immunizálás során. Egy úgynevezett „harmadik generációs” eljárásnál igazoltan nem patogén, replikációra képtelen vírusvektorok genetikai anyagába viszik be a megtermelendő fehérjének (Spike = tüskefehérjének) megfeleló géndarabot. A legújabb, „negyedik” generációs eljárás során magát a tüskefehérjét kódoló messenger RNS-t önmagában, egy lipidmembrán által határolt nanopartikulába csomagolva juttatják a szervezetbe. A gazdaszervezet sejtjei az mRNS-kód alapján megszintetizálják a tüskefehérjéket, amelyek az immunválasz során kiváltják a hosszú távú védelmet okozó immunmemóriát.

\section{A SARS-CoV-2 vírus ellen fejlesztett vakcinák}

Az 1. táblázat a jelenleg ismert információk alapján azokat a védőoltásokat mutatja be, amelyek vagy már klinikai felhasználásra egyes nemzetközi engedélyező hatóság Európai Gyógyszer- ügynökség (EMA), Élelmiszer- és Gyógyszerfelügyelet (FDA) által elfogadottak, vagy legalább a klinikai 2., átmeneti 2/3, vagy klinikai 3 . fázisban vannak. A jelen írás 2021 januárjában készült, tehát, ismerve a vakcinafejlesztés gyorsuló ütemét, valószínúleg a cikk megjelenéséig e tekintetben az információ frissítésre szorul. Állandó, naponta frissített helyzetjelentések állnak rendelkezésre a következő webhelyen: (https://www.nytimes.com/interactive/2020/sci ence/coronavirus-vaccine-tracker.html). A 2. táblázatban a védôoltások regionális befogadását mutatjuk be.

\section{Passzív immunizálás - vakcinálás lehetősége Covid-19 betegségben}

Passzív immunizálás során kívülről juttatják be a megfelelő antitesteket a beteg szervezetébe (3).

$\mathrm{Az}$ első eredmények alapján, a Regeneron laboratóriumában a tüskefehérje ellen elóállított monoklonális antitestkoktél (casirivimab és imdevimab) megakadályozta a tüneti Covid-19fertőzést mintegy 400, idősotthonokban élő önkéntesen. Míg a placebocsoport 223 betegéból 8-nál Covid-tünetek jelentkeztek és a vírus tesztje pozitív volt, addig az antitestet kapott 186 beteg közül egyiknél sem tapasztalták ezt. $\mathrm{Az}$ antitestekkel kezelt önkéntesek szintén kevésbé voltak tünetmentes hordozók a Covid19-et okozó SARS-CoV-2 vírusban. A placebocsoport 23 önkéntesének pozitív vírustesztje volt, szemben az antitestcsoport 10-ével, ami 50\%-os csökkenést mutat.

A Regeneron konkurense, az Eli Lilly két antitestje, a bamlanivimab és az etezevimab kombinált terápiája 70\%-kal csökkentette a Covid-19 betegek kórházi kezelésének és halálozásának kockázatát. A bamlanivimabot 2020 novemberében engedélyezték sürgősségi alkalmazásra

2. táblázat. SARS-CoV-2 elleni vakcinák biotechnológiai megoldásai és felhasználási régiói

\begin{tabular}{lll} 
Fejlesztó & Biotechnológia & Befogadási státusz \\
\hline Pfizer/BioNTech & mRNS & EU, Kanada, USA, Izrael, más országok \\
\hline Moderna & mRNS & EU, USA, Izrael \\
\hline Oxford-AstraZeneca & ChAdvírus & sürgósséggel UK, EU, India, más országok \\
\hline Galameya & Ad26/Ad5 & sürgősséggel Oroszország, Belorusszia, más országok \\
\hline Janssen/J\&J & Ad26 & \\
\hline CanSino & Ad5 & korlátozottan Kína \\
\hline Sinopharm & inaktivált & korlátozottan Kína, EAE \\
\hline SinoVac & inaktivált & Kína, Brazília \\
\hline Bharat Biotech & inaktivált & korlátozottan India \\
\hline
\end{tabular}


enyhe vagy közepesen súlyos Covid-19-ben szenvedő, magas kockázatú betegeknél az Amerikai Egyesült Államokban. A vizsgálatok szerint a bamlanivimab önmagában hatékony, vagy azt jósolják, hogy hatásos lesz az összes olyan törzs több mint $99 \%$-ával szemben, amelyet manapság az Amerikai Egyesült Államokban és az Egyesült Királyságban találtak.

\section{Gyakorlati kérdések a SARS-CoV-2 elleni vakcinációval kapcsolatban}

E tanulmány írásakor az Európai Unióban (EU) és hazánkban is egyelőre a két mRNS-vakcina alkalmazása engedélyezett. A továbbiakban ezeket az egyszerúség kedvéért „Pfizer-” és „Moderna-" vakcinaként fogjuk említeni. A kézirat lezárása előtt jött a hír, hogy Magyarországon engedélyezik az AstraZeneca- és a Galameya adenovírus-vakcináját. A többi fent említett vakcina alkalmazása reálisan még hosszabb időt vehet igénybe. Mindezek miatt az alábbi szempontok tekintetében egyelöre kizárólag a Pfizer- és a Moderna-vakcinával kapcsolatban rendelkezünk megbízható információkkal.

\section{Immunválasz, védettség, ütemezés és védelem a mutánsok ellen}

Elsődleges kérdés, hogy a vakcináció meddig ad védettséget. Jelen pillanatban a klinikai vizsgálatok alapján annyi bizonyos, hogy mind a Pfizer-, mind a Moderna-vakcina legalább három hónapig hatékony. Mivel ezeket

A legújabb eljárás során magát a tüskefehérjét kódoló messenger RNS-t juttatják be a szervezetbe. a védőoltásokat is csak rövid ideje alkalmazzák, később várhatóak a hosszabb távú követések publikációi. Indirekt módon következtetni lehet a természetes Covid-19-fertőzés utáni védettségről. A fertőzést követô antitestválasz 3 hónap után drasztikusan csökkenni kezd (3). Angliai, több mint 12000 egészségügyi dolgozón végzett vizsgálatban viszont a védettség 6 hónapig is eltartott (4). Természetesen a (memória-) sejtes immunitás még hosszabb lehet. Egy 188 Covid-19-betegen végzett, 8 hónapig tartó követéses tanulmányban a SARSCoV-2-specifikus $\mathrm{CD} 4{ }^{+}$T-sejt-válasz féléletideje a fertôzés után 3-5 hónap volt, de a betegek 92\%-ában még 6 hónap után is detektálható volt a specifikus memória-T-sejtes immunválasz (5). A védőoltások közül a Pfizer-vakcina esetében 3-3,5-szer erősebb humorális immunválasz alakul ki, mint a spontán fertôzés során (6), így feltételezhetố a fertőzés után kialakulónál jóval hosszabb védettség. A Moderna-vakcina esetében is igazolódott, hogy az antitestválasz 119 nap után is magas marad, így a védettség biztosan hosszabb 4 hónapnál (7).

Az ütemezés tekintetében két alapvetô kérdés vetődik fel. Egyrészt, hogy mennyire fontos a két oltás közti időtávolságot tartani, másrészt hogyan és mikor kell oltani Covid-19 betegségen átesett vagy PCR-pozitív egyéneket. A Pfizervakcina esetében 21 (6), a Moderna oltóanyagánál 28 nap ajánlott a két oltás között (7). Azért fontos ezt betartani, mert a klinikai vizsgálatok ilyen protokoll szerint történtek. Mindkét oltóanyag esetében van adat hosszabb idóközre is, de a klinikai vizsgálatokban a betegek túlnyomó részét 21, illetve 28 napos szünettel oltották (6, 7). Így nem biztos, hogy hosszabb oltási időköz esetén is ugyanolyan hatékony lesz az oltás. Ennek megfelelően az a jó stratégia, ha az elsô alkalommal oltottak részére mindjárt tartalékolják a második oltást is. Ami pedig a SARS-CoV2-fertôzésen átesetteket illeti, mint láttuk, a humorális védettség 3-6 hónapig $(3,4)$, a sejtes ennél hosszabb ideig tart (5). Ezen belül oltani tehát, bár nem káros, felesleges. Igazából minden fertôzésen átesettnél érdemes lenne monitorozni a nukleokapszid elleni IgG-választ és elégtelen ellenanyagszint esetén oltani, mert az immunválasz egyénileg nagyon változó. Ezt azonban döntôen logisztikai és financiális okokból rutinszerúen nem ajánlják (5).

A SARS-CoV-2-nek legalább kilenc mutánsát fedezték fel. Legismertebb a tüskefehérjében N501Y mutációval rendelkező variáns. Ez gyorsabban terjed a vad típusnál. Amellett, hogy a gyógyszercégek dolgoznak a mutánsok elleni vakcinák kifejlesztésén, például a Pfizer-vakcina esetében kimutatták, hogy e mutáns ellen is megfelelő védettséget alakít ki (8).

\section{Speciális betegcsoportok és állapotok}

A vakcináció kapcsán, nem foglalkozva az oltást teljesen megtagadókkal, egészségesekben nem merül fel komolyabb probléma. Egyedül az oltóanyag komponensei, például a Pfizer-vakcina esetén a polietilénglikol elleni ismert allergia az abszolút ellenjavallat $(9,10)$. Korábbi, más ágens (például védőoltás, gyógyszer, élelmiszer) bevitelét követô anafilaxia nem jelent ellenjavallatot, de ez esetben a védőoltást biztonságos, ellenoorzött környezetben kell beadni $(9,10)$. Bár a Covid-19-vakcinák mellett valamelyest gyakoribb az anafilaxia, mint az influenzaoltások esetén, 
vagy például az Amerikai Egyesült Államok lakosságának összes oltási statisztikáját tekintve (9), de ezekben a populációkban betegek is vannak. Mint azt a norvég gyógyszerügynökség is jelentette (11), idôs betegekben, különösen szociális otthonokban, ahol egyébként is igen magas a halálozás, gyakrabban figyeltek meg fatális szövődményeket a Covid-19-vakcináció kapcsán.

A legtöbb kérdés az autoimmun-gyulladásos betegek és a különböző immunszuppresszív szerekkel kezeltek kapcsán merült fel. A szisztémás autoimmun-gyulladásos reumatológiai kórképek (arthritisek, lupus stb.) vonatkozásában az Európai Reumaliga (EULAR) adott ki állásfoglalást, beleértve a leggyakrabban elhangzó kérdésekre adott válaszokat is. Ennek megfelelően minden betegnek javasolják az EU-ban engedélyezett bármelyik oltást. Ugyanez vonatkozik a kortikoszteroidokra, methotrexatra (MTX) és a legtöbb célzott terápiás készítményre. A rituximab kapcsán, mivel ez a szer a B-sejteket gátolva csökkentheti az oltásra adott immunválaszt, a kezelőorvossal való konzultációt és a rituximab beadása után legalább 3 hónap szünet tartását javasolják (12). Ez az ajánlás kiterjeszthető a nem reumatológiai autoimmun betegekre is. A sclerosis multiplex (SM) kapcsán a Magyar Sclerosis Multiplexes Betege- kért Alapítvány (MSMBA) fogalmazott meg hasonló szemléletú állásfoglalást (13). Hasonlóan ajánlják a védôoltást gyulladásos bélbetegségben (14), psoriasisban (15), coeliakiában (16), autoimmun pajzsmirigybetegségekben (17) szenvedő betegeknek, illetve betegségükre biológiai gyógyszert kapóknak is. Az immunhiányos betegek kapcsán a splenectomizált betegek oltását kifejezetten ajánlják a brit hematológusok (18). A nem immunpatogenezisú kórképekre vonatkozóan a védőoltás biztonságos és ajánlott pszichiátriai betegekben is (19).

Humán reprodukciós kérdéseket illetôen, az mRNS-vakcinák várandósok és szoptató anyáknak nem adhatók, mert az eddigi klinikai vizsgálatokból ezeket a személyeket kizárták, így nem rendelkezünk megfelelő tapasztalattal (10). Ugyancsak kevés az adat a vakcinák fertilitásra gyakorolt hatásáról, mindenesetre biopsziás mintákkal igazolták, hogy a herében magas ACE2-expresszió van, és maga a vírus okoz infertilitást (20), a vakcina valószínúleg nem.

Végül speciális kérdés a sportolók oltása. A Covid-19-vakcina esetében még nem rendelkezünk adattal, de a korábbi összefoglaló elemzések azt mutatták, hogy a sport és a fizikai aktivitás javítja a vakcinára adott immunválaszt (21).

\section{Irodalom}

1. https://covid19.who.int.

2. Pollard AJ, Bijker EM. A guide to vaccinology: from basic principles to new developments. Nat Rev Immunol 2020. https://doi.org/10.1038/s41577-020-00479-7

3. Wang $Y$, Li J, Li H, Lei P, Shen G, Yang C. Persistence of SARS-CoV-2-specific antibodies in COVID-19 patients. Int Immunopharmacol 2020;90:107271. https://doi.org/10.1016/j.intimp.2020.107271

4. Lumley SF, O'Donnell $D$, Stoesser $N E$, Matthews $P C$, Howarth $A$, Hatch $S B$, et al. Antibody status and incidence of SARS-CoV-2 infection in health care workers. $N$ Engl J Med 2020.

https://doi.org/10.1056/NEJMoa2034545

5. Dan JM, Mateus J, Kato Y, Hastie KM, Yu ED, Faliti CE, et al. Immunological memory to SARS-CoV-2 assessed for up to 8 months after infection. Science 2021. https://doi.org/10.1126/science.abf4063

6. Mulligan MJ, Lyke KE, Kitchin N, Absalon J, Gurtman A, Lockhart $S$, et al. Phase I/II study of COVID-19 RNA vaccine BNT162b1 in adults. Nature 2020;586(7830):589-93. https://doi.org/10.1038/s41586-020-2639-4

7. Widge AT, Rouphael NG, Jackson LA, Anderson EJ, Roberts $P C$, Makhene $M$, et al. Durability of responses after SARSCoV-2 mRNA-1273 vaccination. N Engl J Med 2021;384 (1):80-2. https://doi.org/10.1056/NEJMc2032195

8. Xie X, Zou J, Fontes-Garfias CR, Xia H, Swanson KA, Cutler $M$, et al. Neutralization of N501Y mutant SARS-CoV-2 by BNT162b2 vaccine-elicited sera. bioRxiv. 2021. https://doi.org/10.1101/2021.01.07.425740

9. https://www.cdc.gov/mmwr/volumes/70/wr/mm7002e1.htm.
10. https://www.ema.europa.eu/en/documents/rmp/comirnaty-epar-risk-management-plan_en.pdf.

11. https://legemiddelverket.no/nyheter/covid-19-vaccinationassociated-with-deaths-in-elderly-people-who-are-frail.

12. https://www.eular.org/eular_sars_cov_2_vaccination_ rmd patients.cfm.

13. https://www.msmba.hu/az-orvostarsasag-ajanlasa-a-covid19-vedooltasrol-sm-betegeknek/.

14. https://crohnsandcolitis.org.uk/news/latest-coronavirusvaccine-for-people-with-crohns-or-colitis.

15. https://www.psoriasiscouncil.org/blog/IPC-Statement-onSARS-CoV-2-Vaccines-and-Psoriasis.htm.

16. https://www.theceliacsociety.org/sscd_news.

17. https://www.btf-thyroid.org/covid-19-and-vaccines.

18. https://b-s-h.org.uk/media/18292/covid19-bsh-guidanceon-splenectomy-v2-final-6-may2020_.pdf.

19. Warren $N$, Kisely $S$, Siskind D. Maximizing the uptake of a COVID-19 Vaccine in people with severe mental illness: A public health priority. JAMA Psychiatry 2020. https://doi.org/10.1001/jamapsychiatry.2020.4396

20. Achua JK, Chu KY, Ibrahim E, Khodamoradi K, Delma KS, lakymenko $O A$, et al. Histopathology and ultrastructural findings of fatal COVID-19 infections on testis. World J Mens Health 2021;39(1):65-74. https://doi.org/10.5534/wjmh.200170

21. Pascoe AR, Fiatarone Singh MA, Edwards KM. The effects of exercise on vaccination responses: a review of chronic and acute exercise interventions in humans. Brain Behav Immun 2014;39:33-41. https://doi.org/10.1016/j.bbi.2013.10.003 